\title{
Hydraulic Modelling Analysis for Road Stormwater Drainage Evaluation under RCPs Based Rainfall Data
}

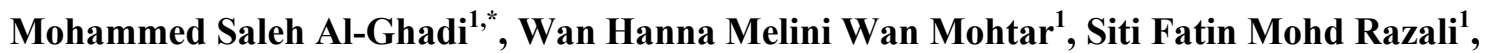 \\ Ahmed El-Shafie ${ }^{2}$
${ }^{1}$ Department of Civil and Structural Engineering, Faculty of Engineering and Built Environment, National University of Malaysia, 43600, Bangi, Selangor, Malaysia
${ }^{2}$ Department of Civil Engineering, Faculty of Engineering, University of Malaya, 50603 Kuala Lumpur, Malaysia

Received October 5, 2020; Revised December 2, 2020; Accepted December 13, 2020

\section{Cite This Paper in the following Citation Styles}

(a): [1] Mohammed saleh Al-Ghadi, Wan Hanna Melini Wan Mohtar, Siti Fatin Mohd Razali, Ahmed El-Shafie, "Hydraulic Modelling Analysis for Road Stormwater Drainage Evaluation under RCPs Based Rainfall Data," Civil Engineering and Architecture, Vol. 8, No. 6, pp. 1335 - 1349, 2020. DOI: 10.13189/cea.2020.080617.

(b): Mohammed saleh Al-Ghadi, Wan Hanna Melini Wan Mohtar, Siti Fatin Mohd Razali, Ahmed El-Shafie (2020). Hydraulic Modelling Analysis for Road Stormwater Drainage Evaluation under RCPs Based Rainfall Data. Civil Engineering and Architecture, 8(6), 1335 - 1349. DOI: 10.13189/cea.2020.080617.

Copyright $\mathrm{C} 2020$ by authors, all rights reserved. Authors agree that this article remains permanently open access under the terms of the Creative Commons Attribution License 4.0 International License

\begin{abstract}
Road drainage systems are often-constructed utilised design approaches not incorporating process-based depictions of possible hydrological responses, resulting in insufficient systems due to infrastructural development and climate change and ultimately, increased hydrological reaction. This study assessed possible effects of precipitation intensity variation following future severe rainfall events on the current road drainage system as whether pre-climatic stormwater drainage system could withstand potentially higher discharges and the need for modified design guidelines incorporating possible precipitation intensity variations due to climate change. A case study was undertaken utilising rainfall data to develop an intensity-duration-frequency (IDF) curve representing precipitation volume variations due to climate change. The peak discharge and water level were simulated using hydraulic software program SWMM 5.1 for the existing open drainage system, wherein three future potential climate scenarios, namely 2030, 2040, and 2050 were simulated based on the RCP4.5 and RCP8.5 scenarios. The simulation results showed a tremendous future precipitation increment for RCP4.5 and RCP 8.5 scenarios, yielding the following values, respectively: $28.8 \%, 43.7 \%$ and $34.6 \%$ and $65 \%, 61.5 \%$ and $75.5 \%$. Therefore, the study findings and approach implemented should be considered when detailing assessments and preserving areas are at risk of high water flows. The study concludes that the existing road drainage system's inadequacy to
\end{abstract}

manage copious rainfall amounts anticipated due to climate change. Therefore, the study contributes to suggest the need for developing drainage system magnitude using higher return periods to mitigate flood levels on urban road networks.

Keywords Intensity-Duration-Frequency (IDF) Curve, Extreme Rainfall Changes, Road Drainage Infrastructure, Climate Change, Urban Flash-Flood, SWMM

\section{Introduction}

Climate change outcomes are not just changes in average temperature; one may describe it in its role towards changes in natural phenomena such as extreme weather, wind, snow, floods, and rising sea levels that can directly impact human life [1]. As such events are capable of causing substantial losses and damage to the citizen properties, each nation has to plan for its customised country-level adaptation. In particular, rises in local heavy rainfall and severe precipitation events have underlined the need for a variety of studies on climate change and its influence on urban zones. Accordingly, several scholarly efforts have been directed to the effect of climate change on urban drainage systems for metropolitan areas [2-8]. 
Many experts have now recognised climate change as a fact and the high possibility of extreme events of temperature and rainfall in the future [9-19]. In general, drainage infrastructures are constructed based on their capacity to move through design discharges and situations in which the effects of a failure are serious, such as a 1-in-100-year flood. Following this, climate change, which can instigate rainfall, will also augment the recurrence of such design discharges and thus impact small and large drainage networks alike, which are built to transfer excessive runoff when the small drainage network capacity is exceeded [20-25]. This begs the question: are new guidelines required to add potential changes in the calculated precipitation intensity result following climate change?

The effect of heavy rains on the urban drainage system can be simulated and analysed using the Regional Climate Model (RCM) [24]. In [26], the characteristics of such systems have been analysed in consideration of the A2 and B2 scenarios under the umbrella of Special Report on Emissions Scenario (SRES) families. They consist of $\mathrm{A} 1, \mathrm{~A} 2, \mathrm{~B} 1$, and B2 scenarios, whereby each is associated with common themes such as changes in population, energy sources, economic growth, and more. The latest case study in the United States (US) has estimated the impacts of climate change on highways, bridges, coastal resources, and urban drainage systems, wherein it specifically underlines the vulnerability of different scenarios, such as greenhouse gas emissions, environment resilience, and global climate models [27]. The study findings have indicated that the resulting effects in this field will be massive, especially in the latter half of the 21 st century following the worsening increments of sea level, temperature, and trends of rainfall, thus influencing the durability of long-lived infrastructure.

Following this, [28] has offered a detailed overview of the latest cutting-edge methodologies for assessing the effect of climate change on an urban catchment area. Similarly, $[29,30]$ have revealed the varying limitations behind the concept of precipitation characterisation in a changing environment for the purpose of urban drainage system planning and operations. Meanwhile, [31] has proposed a transdisciplinary and integrated approach to sustainable drainage design, whereas [32] has studied the hydraulic efficiency of urban drainage networks in relation to rainfall changes, thus identifying the effect of climate change by using hydraulic parameters like the water level in nodes (i.e. flood numbers, flood frequency and duration) and pipeline flow ratio. Moreover, the recent events have further illustrated the need for a direct rainfall representation in hydraulic models [33], thus reflecting that such enhanced capacity will allow a better assessment of flood damage on roads and other additional improvements to transport networks. Contrarily, fewer studies have been done to record the total hydraulic efficiency of transport facilities (i.e. culverts, pipes, and bridges) subjected to severe climate conditions in the future [34].

Road networks are perceived as particularly susceptible to climate change [35], whereby the combination of potential changes in severe flooding and the lack of awareness about the appropriate infrastructure adaptation to such change has caused such vulnerability $[35,36]$ in the short and long-term contexts [37]. In this case, flooding and high levels of water can pose a major effect on road network performance and lifespan both as these incidents influence the number of accidents that occur, such as ground slides, landslides, highways being washed away, collapsed and damaged bridge supports, and damaged roadworks [38]. Therefore, mitigating the effects of these risks renders it highly essential for one to ensure the quality and security of the current facilities (i.e. roadways), whereby extended-term planning is especially significant for the present and future infrastructures. This allows structures such as highways and bridges to have a longer service life. Besides, in response to the expected changes in the future climate, the standards for designing new road-based constructions have been revised in several countries $[39,40]$, which requires the effort to prepare the existing and future road drainage schemes to incorporate the combined effect of future environment.

Furthermore, the rising and expanding road network-related efforts are related to economic development, sustainability and social security $[39,41]$, whereby climate change threatens economic growth and development and the social welfare benefits associated with infrastructure expansion. The vulnerability of transport-based infrastructures to climate change $[42,43]$ has yielded research efforts on the quantified economic influences of changing climate towards Alaskan public infrastructure under comparatively low and high weather. This was done in the context of scenarios reflecting the RCP4.5 and RCP8.5, whereby the medium stabilisation scenario and high baseline emission scenario of concentration pathways were respectively found road flooding to be the primary cause of harm. This was specifically caused by increased rainfall and followed by harm to near-surface permafrost melt buildings, whereas less damages to airports, railways, and pipelines were observed [44]. Accordingly, Yunianta et al. [45] has established a sustainable road drainage system by improving its capacity to allow water pertinent in road construction to seep into the soil by providing artificial facilities, whereas [46] has conducted the SWMM program simulation framework to evaluate the current road drainage network and incorporate a sustainable road drainage system.

As such, the Intergovernmental Panel on Climate Change (IPCC, 2013) has proposed the Representative Concentration Pathways (RCPs), which are a collection of greenhouse gas concentration and emission pathways designed to study the effects and 
future policy responses of climate changes $[47,48]$. It encompasses the spectrum of rates of force correlated with emission scenarios as reported in the literature, following which it is classified into four separate scenarios according to the degree of carbon dioxide reduction. For example, RCP 8.5 denotes a strong pathway of greenhouse gas emissions according to the literature on the scenarios [47,49], which is also called the "baseline" scenario without any specific climate reduction plan. In this case, the greenhouse gas emissions and concentrations would increase significantly over time and thus results in a radiative force of $8.5 \mathrm{~W} / \mathrm{m} 2$ by the end of the century.

In this research, the latest emission scenarios otherwise called as RCPs are implemented despite its seldom use in Malaysia [50]. RCPs can paint a stronger picture of the potential greenhouse gas concentration for climate model running in comparison with previous scenarios [51,52]. Therefore, this study undertakes an analysis by using the medium (RCP4.5) and high (RCP8.5) scenarios by introducing a process-based modelling experiment. It is aimed to explore the possible effects of future storm events on the network of road drainage under current and future scenarios to investigate the effectiveness of the existing designs. Such goal is achieved via an analysis of scenarios involving severe weather conditions for a specific group of road drainage networks towards the Blue State Lake catchment, which is located in Seri Kembangan, Malaysia.

The essential innovative aspect positioned in this case is the application of hydraulic modelling on high and medium RCP emission scenarios to show a possible "way forward" for road designers to properly understand the impacts of climate change. Besides, it will be positioned towards checking whether the current road drainage systems that are designed using a non-process-based methodology for hydrological estimation are adequately appropriate in coping with future climate changes. The assumption made underlines that the existing drainage systems are insufficiently scaled as climate change will lead to hydrological responses that are insufficiently anticipated when using the non-process-dependent approaches.

As such, this paper highlights the hydraulic efficiency of road drainage systems found in urban areas, wherein its ultimate goal is to investigate the hydraulic impacts of heavy runoff, runoff depth, and peak discharge on the system as a result of variations. Therefore an attempt is made to develop a methodology for assessing the road drainage system and its impacts on road structure based on historical and predicted precipitation data.

\section{Materials and Methods}

\subsection{Study Area}

Sungai Besi Expressway (SBE) or otherwise commonly known as the BESRAYA highway is located on the eastern side of Kuala Lumpur. Constructed in 1997 by Road Builder (M) Holdings Berhad, the expressway was initially $16 \mathrm{~km}$ long but has since been extended to its current $28.3 \mathrm{~km}$-long length (as of Dec 2015). It begins at the Universiti Putra Malaysia (UPM) Interchange, wherein it connects the users to Kuala Lumpur via the North-South Expressway.

The (South) highway station No. $2.6 \mathrm{~km}$ is located in the low topography region of Seri Kembangan municipality, which is located between the latitude $3^{\circ}$ $01 ' 22.3$ "N and longitude $101^{\circ} 43^{\prime} 00.2 \mathrm{NE}$ (Figure 1). The study area consists of $0.472 \mathrm{~km}^{2}$ made up of roughly $60 \%$ and $40 \%$ urban and green lands, respectively, whereby $80 \%$ of its area has an elevation below $40 \mathrm{~m}$ and $60 \%$ has a slope below 5\%. Located within the main Kuyuh River catchment, SBE discharges into the blue-water estate and silty clay has been identified as the principal soil in the green land area.

The region of Seri Kembangan can be characterised by a warm and sunny tropical rainforest climate along with abundant rainfall, which is particularly documented from October to March during the north-eastern monsoon season in a year. The temperature is usually stable; its maximum ranges from 31 to $33^{\circ} \mathrm{C}$, while its minimum range spans from 22 to $23.5^{\circ} \mathrm{C}$. The region normally receives a total of $2600 \mathrm{~mm}$ of rain each year, whereby the months of June and July are fairly dry despite the amount of rainfall generally reaching $133 \mathrm{~mm} /$ month then. A drainage photo taken on 21 September 2015 depicted some of the flood events that occurred during a storm rainfall, showing that the system could easily exceed its capacity (Figure. 1). 


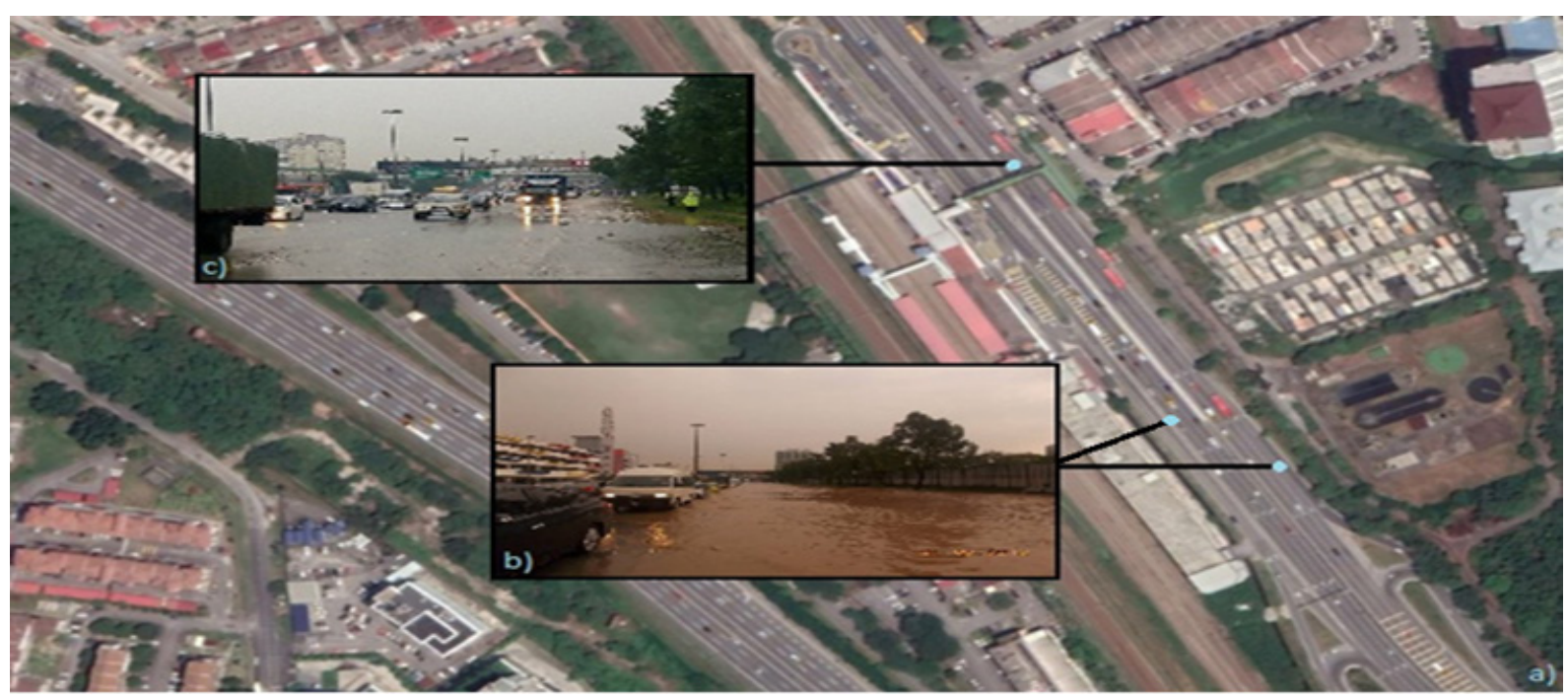

Figure 1. Topographic area map (i.e. a, b, and c) photographs of flood impacts on both roadway directions, April 2015.

This area was specifically chosen in this study due to its prevalently described vulnerability to floods and associated road damage $[53,54]$. As such, the research focused on the main road stormwater drainage scheme typically occurring along the road streams (Table 1).

Table 1. Characteristics of road drainage in the study area

\begin{tabular}{|c|c|c|l|}
\hline Structure & Shape & $\begin{array}{c}\text { Dimensions } \\
\text { (diameter) [m] }\end{array}$ & Materials \\
\hline $\begin{array}{c}\text { Open } \\
\text { channel }\end{array}$ & Trapezoidal & $\begin{array}{c}0.45-0.45 \text { and } \\
0.70-0.50(\mathrm{~d}-\mathrm{w})\end{array}$ & Concrete \\
\hline $\begin{array}{c}\text { Open } \\
\text { channel }\end{array}$ & Rectangular & $\begin{array}{c}0.75-1.20 \text { to } \\
1.80-2.20(\mathrm{~d}-\mathrm{w})\end{array}$ & Concrete \\
\hline Pipe & Circular & 0.80 & Concrete \\
\hline
\end{tabular}

Such types of drainage systems are usually conceived according to local requirements throughout the major roads in Malaysia [55].

\subsection{Rainfall and Climate Model Input Data}

In general, IDF curves are one of the most widely utilised techniques in the engineering of water resources; the planning, designing and operation management of water schemes; or the protection of many flood-prevention construction projects [25,56-59]. Therefore, the commonest type of design rainfall data necessary for peak discharge estimation purposes was identified via the relationship represented in the curves, which could be established by using the historical rainfall data. Such data were typically accessible for a majority of the geographical areas in Malaysia, which were subjected to interpolation and smoothing. In addition, it is highly suggested for the curves to be developed directly from the local rain gauge records should such information are adequately long and reliable.

Furthermore, an emphasis should be made regarding the intended use of rainfall temporal patterns in hydrograph generation design storms. In general, the design patterns were not a derivative of complete storms; instead, they were obtained from the acute bursts of rainfall data recorded over a specific duration. Therefore, the temporal rainfall patterns are developed while the standard time intervals that are recommended for urban stormwater modelling are listed in Table 2.

Table 2. Recommended Intervals for Design Rainfall Temporal Pattern [55]

\begin{tabular}{|c|c|}
\hline Storm Duration (min) & Time Interval (minutes) \\
\hline Less than 60 & 5 \\
\hline $60-120$ & 10 \\
\hline $121-360$ & 15 \\
\hline Greater than 360 & 30 \\
\hline
\end{tabular}

The Maximum rainfall intensity can be determined using an appropriate theoretical distribution function was utilised to approximate the peak runoff of each sub-catchment and input parameter in the runoff simulation in the Stormwater Management Model (SWMM) 5.1. Accordingly, the process of developing the IDF curves is shown step-by-step in Figure 2. In this work, three parts were implemented: (1) developing the IDF curves derived from 10-year rainfall data (2008-2017) available as provided by the rainfall stations of Seri Kembangan city by using the best-fitted distribution; (2) assessing the maximum discharge from the catchment using the rational formula; and (3) undertaking a capacity assessment of existing road stormwater drainage system based on the design storm intensity obtained from the IDF curves.

The capacity analysis of the existing drainage network for the chosen study area was carried out by employing SWMM 5.1, whereas the historical rainfall event characteristics were simulated over the 1, 2, and 3-hr storm durations at 5, 10, and $15 \mathrm{~min}$ intervals, respectively. This was done based on the design storm intensity obtained from the IDF curves. Furthermore, future rainfall events were attained and employed due to 
their prediction by the National Hydraulic Research Institute of Malaysia (NAHRIM). Therefore, the low and high climate forcing scenarios (i.e. RCP4.5 and RCP8.5) were simulated for the periods of 2030, 2040, and 2050.

Graphical analysis was conducted using the graphical interface of the MATLAB fitting method. The data included

three separate types of probability distribution functions (GEV, lognormal and Gumbel). For precipitation data, Gumbel 's distribution offered a better fit than GEV and Log normal distributions based on the Kolmogorov-Smirnov (KS) and Shapiro-Wilk test of goodness of fit used to determine the suitability of various probability distributions, as shown in Figure 3. The purpose of the frequency analysis is to relate the magnitude of events to their frequency of occurrence through the distribution of probability for different return periods.

To construct the IDF curves, procedures similar to (Figure 2) above as given in the Urban Stormwater Management Manual for Malaysia [55] were performed for $0.05,0.10,0.15,0.30,1,2,3,6,12,24$, and 48 hours and at the 2, 5, 10, 20,50, and 100-year return periods. The subsequent findings are revealed in (Figure $4)$.

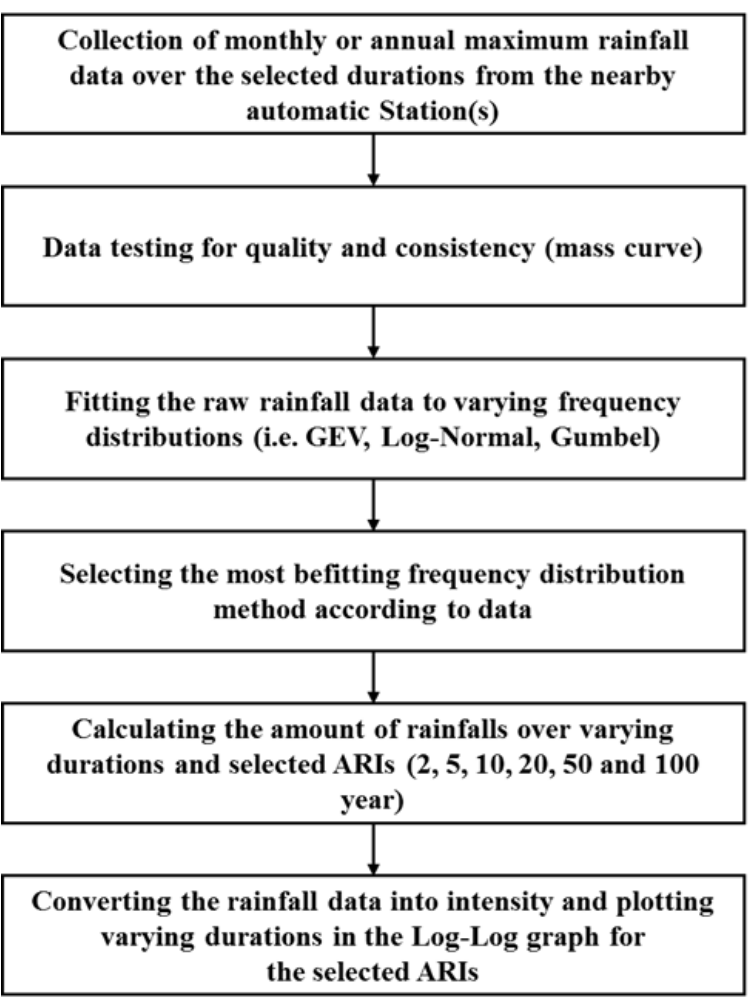

Figure 2. Common steps for IDF curve development [55]

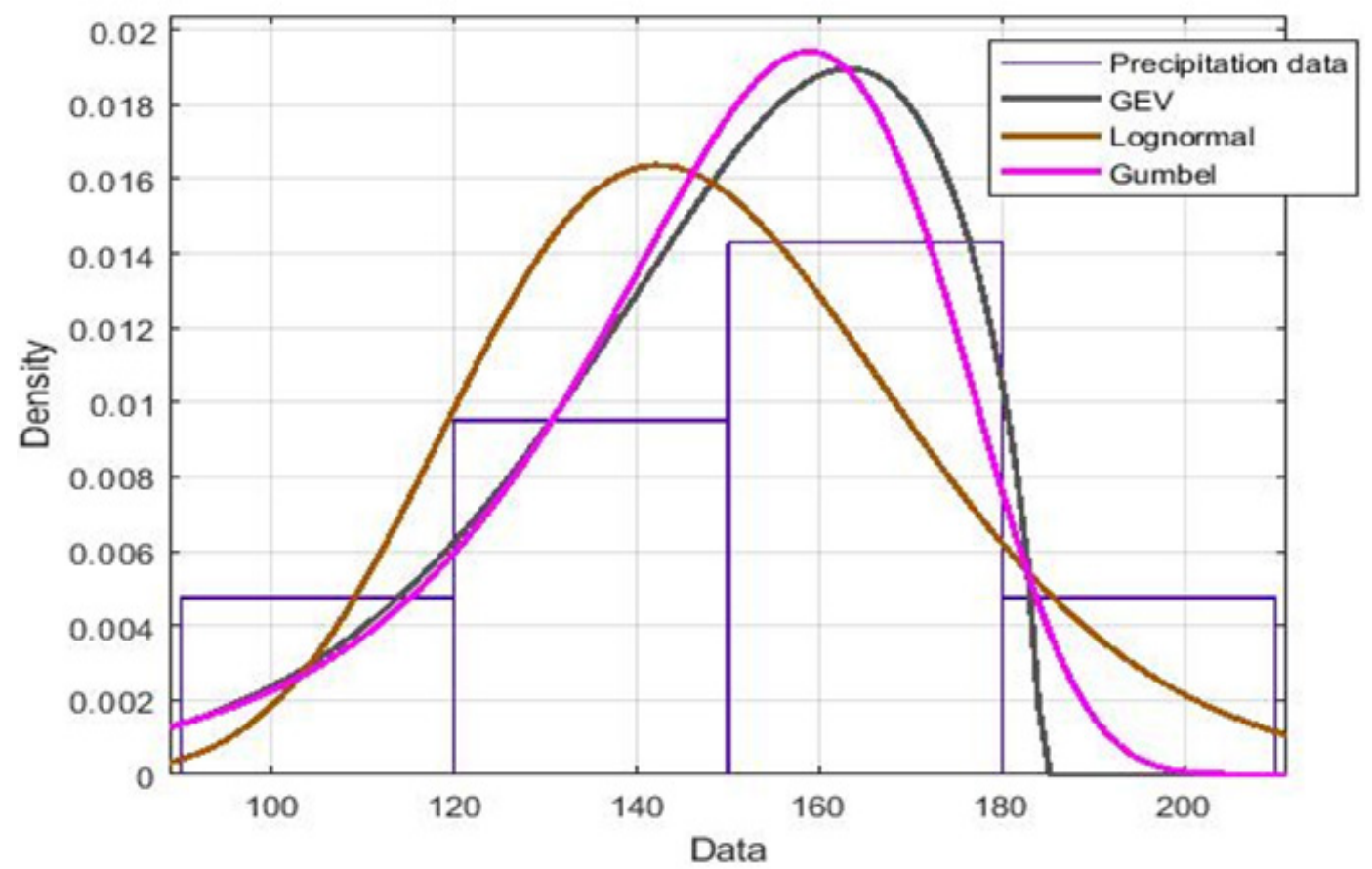

Figure 3. Histogram of maximum precipitation for the 24-h duration and the fitted probability density function (2008-20017) 


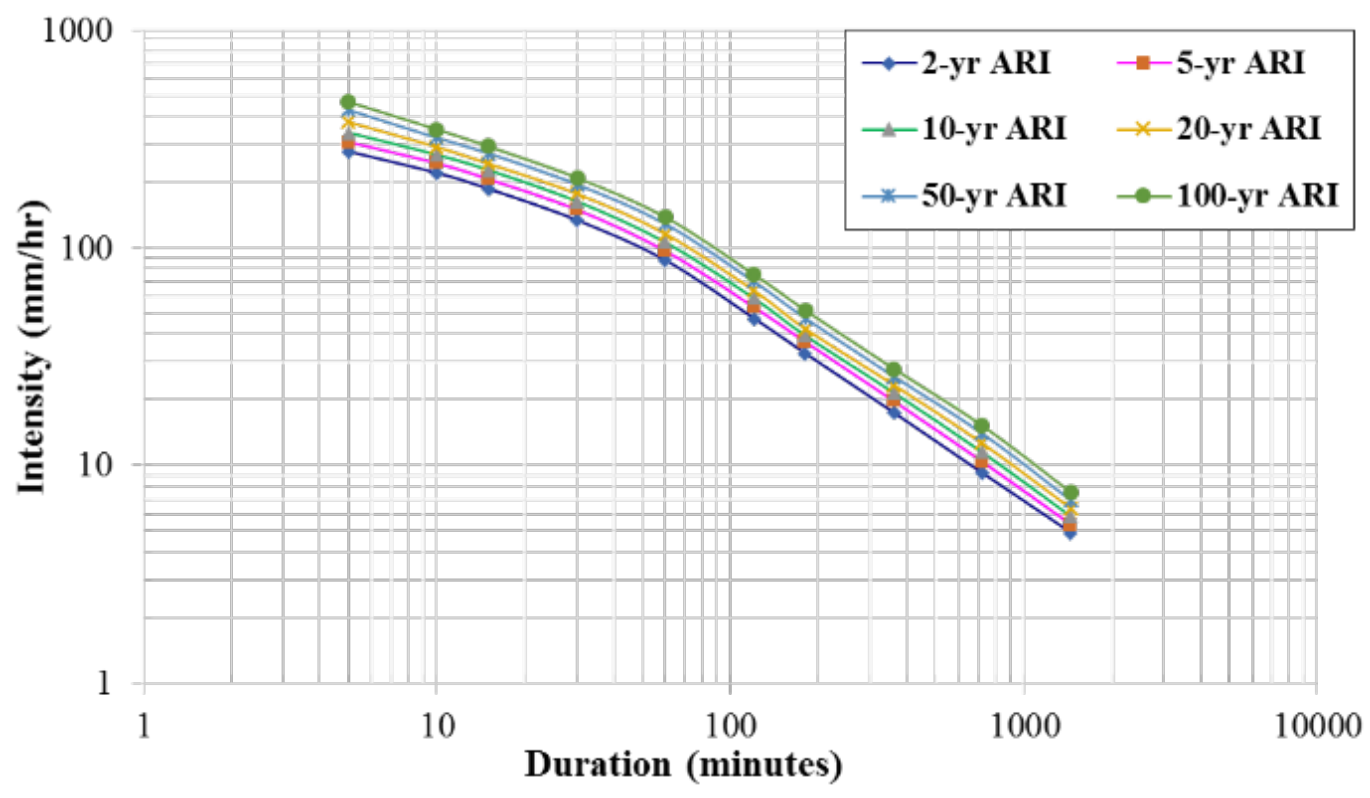

Figure 4. Typical IDF curves for the region of Seri Kembangan

In addition, runoff simulation was also undertaken to conduct ongoing simulations of current and predicted hydrology data.

\subsection{Rainfall-Runoff Modelling}

The EPA SWMM 5.1 is a complex model system that allows a rainfall-runoff simulation for a singular event or a long-term (continuous) simulation of runoff quantity and quality in urban locations [60]. This software has been used regionally in multiple previous studies $[13,58]$ and proven to be suitable for the task in hand. Therefore, the latest edition of EPA SWMM version 5.1.013 was employed in analysing the potential adverse effect of rising rainfall intensity caused by a climate change on the current drainage network regarding its capacity to carry the excess runoff.

As the drainage of urban road networks in Malaysia was also constructed to include the collection of additional inflows from the upstream catchment areas, up to $5 \mathrm{~km}$ of road drainage network was divided into nine sub-catchments and modelled by SWMM 5.1 (considering the abilities of the model). First, the calculation of each sub-basin area was done and then provided as the input in SWMM 5.1 in defining the runoff from each sub-catchment (i.e. sub-basins are denoted as sub-catchments in SWMM). Then, the overland flow from each sub-catchment was measured via the rational formula and the SWMM model simulation was done for the calculated flow values in order to identify the flooding junctions. Accordingly, dynamic wave routing was thus denoted as the approach for flow routing in simulating the runoff into the drainage network, thereby calculating the impacts of backwater. Concurrently, it could model the reverse, mixed, and rapidly-changing flows. Meanwhile, the infiltration process was modelled by implementing the curve number $(\mathrm{CN})$ method as the value is obtained according to the type of land use and thus identifiable in the SWMM User Manual. (Figure 5) below illustrates the model framework accordingly.

The borderline of all sub-catchments was calculated based on the runoff flow through the junctions to drainage by using a current drainage network structure map at the scale of 1:2000. Each sub-catchment width was determined by dividing the zone in the particular sub-catchment by the longest waterway, whereas other information required to simulate the urban drainage system (i.e. drainage network sizes and junction elevation) was obtained from the archived sketch maps kept by the Malaysian Highway Authority study region was below $40 \mathrm{~m}$, a rain gauge was applied for the entire sub-catchment, whereby the modelled network ultimately comprised 17 junctions. This includes an outfall node and 16 conduits as illustrated in (Figure 6). 


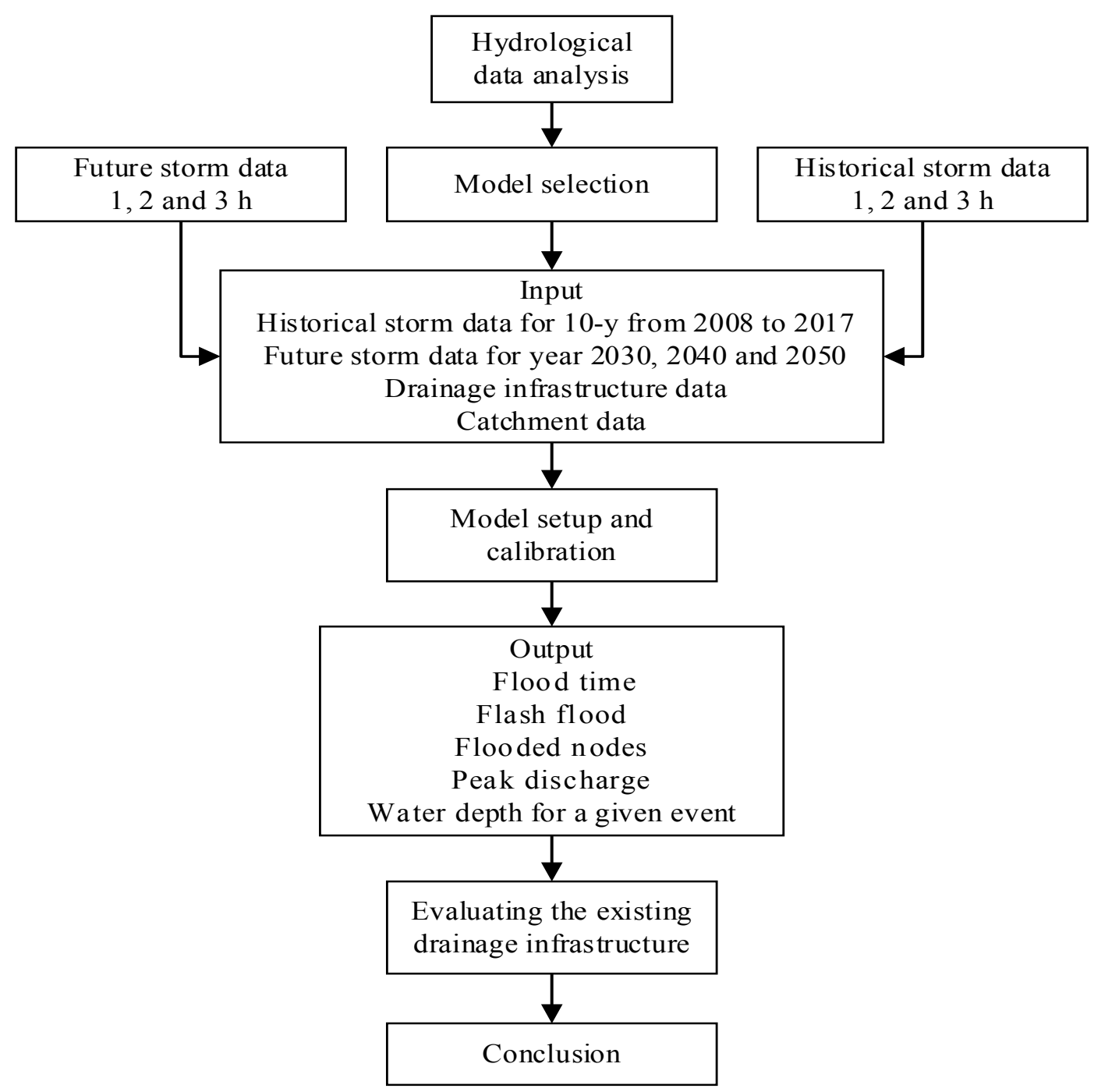

Figure 5. Model framework used in the study

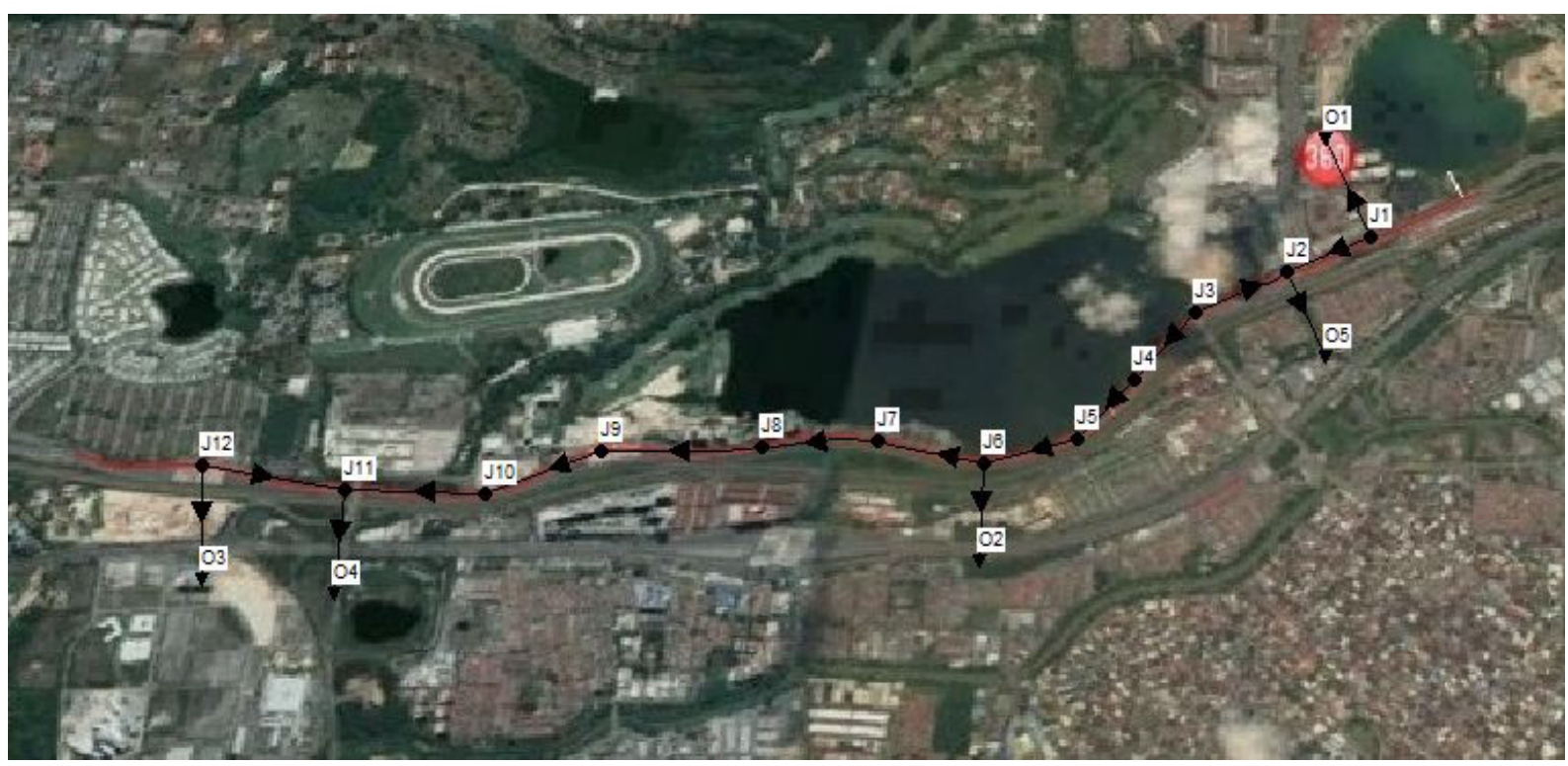

Figure 6. Sketch of the drainage network in the SWMM Model 
As illustrated in the above figure, the most flooded nodes are 2, 3, and 4, while nodes 5, 8, and 9 denote full drainage and the remaining nodes are not affected. Based on the secondary rainfall-event analysis data by BESRAYA (Road Builder (M) Holdings Berhad), the design rainfall duration was considered as 2-hour in association with the 10-year return period based on the recommended design criteria [55]. Moreover, a 10-minute time step was implemented in designing a time series of rainfall as the model input, while the time interval of 15-minute was allocated for long-term continuous input precipitation. Note that this study dismissed the reduction in conduit capacity (i.e. due to deposition or blockage) for the transition into the runoff.

\subsection{Model Calibration}

Model calibration was conducted to find an appropriate modelling outcome and observations were made regarding links in describing the peak discharge and depth of rainfall in the road catchments. First, daily rainfall series for the study area were obtained from the Department of Irrigation and Drainage (DID) and the model was employed based on the 10-year rainfall data spanning from 01 January 2008 to 31 December 2017. This period was further derived from the duration of the year 1970 to 2017 since it corresponded to high-quality rainfall data. Meanwhile, the present road classification was considered as a high volume road at a speed limit of $70 \mathrm{~km} / \mathrm{h}$, whereas the drainage was planned for a return period of 10 years in view of the Malaysian Stormwater Management Manual [55].

Furthermore, the rational method is known as the most widely employed approach for estimating the peak-runoff in Malaysia; it has been recommended in several drainage manuals [61] specifically for road drainage system construction. The approach is particularly good for small drainage catchments, whereby it can be expressed as:

$$
Q=\frac{C \cdot i \cdot A}{360}
$$

where,

$$
\begin{aligned}
& \mathrm{Q}=\text { Peak flow }\left(\mathrm{m}^{3} / \mathrm{s}\right) \\
& \mathrm{C}=\text { runoff coefficient, } \\
& \mathrm{i}=\text { average rainfall intensity }(\mathrm{mm} / \mathrm{h}), \text { and } \\
& \mathrm{A}=\text { drainage area }
\end{aligned}
$$

The above formula was employed for 46.85 hectares $\left(0.4685 \mathrm{~km}^{2}\right)$ of the total area, wherein the maximum calculated peak discharge for the study area was $3.88 \mathrm{~m}^{3} / \mathrm{s}$, while the simulated peak discharge was 4.8 $\mathrm{m}^{3} / \mathrm{s}$ for a 24 -hour duration and 10-year return period. Table 3 compares the reported and simulated flood depths in the study area accordingly.

In the study, the simulated flood depth of a storm was compared to the observed flood depth. Due to the manual calibration and validation processes and in response to the peak discharge obtained for the calibration and maximum storm depths for validation purposes, a good match was found between the measured and modelled results.

\section{Results and Discussion}

\subsection{Runoff Simulation and Modelling Result Analysis}

The runoff simulation was undertaken in this study by using SWMM 5.1 to examine whether the rising rainfall intensity following climate change would adversely affect the current drainage structure for excess runoff communication. The IDF curves were simulated using the maximum rainfall intensity of 1,2 , and 3-hr storm durations and 10-year return periods so as to define the peak discharge, rainfall depth, and short-lived flash flood (Table 4).

The modelling results indicated a $23.7 \%$ rise of the maximum peak stormwater runoff as a result of the rising intensity from $46.6 \mathrm{~mm} / \mathrm{h}$ to $58.8 \mathrm{~mm} / \mathrm{h}$ according to the empirical equation. This was then implemented to reduce any errors in estimating the rainfall intensity values using the IDF curves over the 10 -year return period and 2-hour duration. (Table 4)

Table 3. Comparison of flood depth for drainage structure in different storm events at SBE based on the reported and simulated flood depths in 2019

\begin{tabular}{|c|c|c|c|c|c|c|}
\hline Events & $\begin{array}{c}\text { Flash flood } \\
\text { location }(\mathrm{km})\end{array}$ & $\begin{array}{c}\text { Reported Storm duration } \\
\text { (h) }\end{array}$ & $\begin{array}{c}\text { Recorded storm } \\
\text { depth (mm) }\end{array}$ & $\begin{array}{c}\text { Observed flood } \\
\text { depth (m) }\end{array}$ & $\begin{array}{c}\text { Simulated flood } \\
\text { depth (m) }\end{array}$ & $\begin{array}{c}\% \\
\text { error }\end{array}$ \\
\hline $24^{\text {th }}$ Apr 2013 & $\begin{array}{c}2300 \text { to } 2700 \\
\text { both road directions }\end{array}$ & 2 & 93 & 0.80 & 0.722 & 10.8 \\
\hline $21^{\text {st }}$ Apr 2014 & $\begin{array}{c}2300 \text { to } 2700 \\
\text { both road } \\
\text { directions }\end{array}$ & 2 & 98 & 0.80 & 0.883 & 9.4 \\
\hline $15^{\text {th }}$ Nov 2014 & $\begin{array}{c}2700 \text { to } 2900 \\
\text { one road direction }\end{array}$ & 2 & 67 & 0.20 & 0.156 & 28.2 \\
\hline
\end{tabular}

Table 4. Characteristics of the historical events at the drainage facility included in the simulation

\begin{tabular}{|c|c|c|c|c|c|c|c|c|}
\hline Event & $\begin{array}{c}\text { Duration } \\
(\mathrm{h})\end{array}$ & ARI & $\begin{array}{c}\text { Peak discharge } \\
\left(\mathrm{m}^{3} / \mathrm{s}\right)\end{array}$ & $\begin{array}{c}\text { Rainfall depth } \\
(\mathrm{mm})\end{array}$ & $\begin{array}{c}\text { First flood } \\
\text { time }(\mathrm{t})\end{array}$ & $\begin{array}{c}\text { Flash flood } \\
\text { node }\end{array}$ & $\begin{array}{c}\text { Flash flood } \\
\text { time }(\mathrm{t})\end{array}$ & $\begin{array}{c}\text { Flood depth } \\
(\mathrm{m})\end{array}$ \\
\hline \multirow{2}{*}{$\begin{array}{c}\text { Historical } \\
\text { event in } \\
21 / 04 / 2014\end{array}$} & $1-\mathrm{h}$ & 10 -year & 5.352 & 98 & $00: 30$ & $2,3 \& 4$ & $01: 00$ & 1.452 \\
\cline { 2 - 29 } & 2-h & 10 -year & 6.380 & 98 & $00: 45$ & $2 \& 3$ & $01: 35$ & 0.883 \\
\hline
\end{tabular}




$$
i=\frac{\lambda T^{\kappa}}{(d+\theta)^{\eta}}
$$

where,

$\mathrm{i}=$ Average rainfall intensity $(\mathrm{mm} / \mathrm{hr})$;

$\mathrm{T}=$ Average recurrence interval $-\mathrm{ARI}(2 \leq \mathrm{T} \leq 100$ year);

$\mathrm{d}=$ Storm duration (hours), $0.08 \leq \mathrm{d} \leq 48$; and

$\lambda, \kappa, \theta$ and $\eta=$ Fitting constants dependent on the raingauge location

Based on the IDF curves developed, Table 5 shows that an increment of $26.18 \%$ for rainfall intensity is observed over the same duration and period of return.

Next, design calculations were made step-wise for the drainage network in the area of research, whereby the minimum drainage channel measurements were 0.45 $\mathrm{m} \times 0.45 \mathrm{~m}$. The average area contributing to the drainage network was $0.4685 \mathrm{~km}^{2}$, whereby the designed principal channel of rainfall intensity was revealed to be $93.2 \mathrm{~mm}$. Meanwhile, the current design rainfall intensity was approximately $117.7 \mathrm{~mm}$ following its measurement, thus revealing that the actual stormwater system dimension was $26.3 \%$ lower than the channel estimated in the current study.

\subsection{The Impact of Future Storm Events}

Future changes in the rainfall amount contributed to a significant rise in peak discharge, whereas the frequency of storm-size changes varied over time. Regardless, the magnitude of peak discharge in the road catchment for the current study region was fairly high, which was dependent on the drainage size and watershed to a certain extent. Furthermore, the rate of precipitation for two hours at a 10 -year frequency was $46.6 \mathrm{~mm}$, indicating that the current drainage network could accommodate $46.6 \mathrm{~mm}$ of rainfall throughout 2 hours of rainfall. Meanwhile, the predicted rainfall storms were compared to the current drainage design guidelines so as to reflect the rainfall depth changes.

Two RCPs, namely RCP4.5 and RCP8.5, were employed in this study for assessing the possible effects of climate change on streamflow characteristics. Accordingly, the modelling was carried out based on the projected worst case (i.e. maximum precipitation) of both scenarios to describe the potential peak discharge, rainfall intensity variability, and flash flood events.

In general, both RCP 4.5 and RCP 8.5 rainfall scenarios exceeded the designed road structures in all three future prediction periods of 2030, 2040, and 2050 . Moreover, the maximum flood depth for short periods was recorded in the year 2050 by using RCP 8.5 , whereby the first flood time initiated during the first 0:10 min up until 0:50 min and the flash flood occurred during 1:00 to 2:10 hours. Therefore, this indicates that the drainage system would be at the maximum flash flood risk in short possible durations. In all scenarios, the most obvious flooded nodes are seen at nodes 2, 3, and 4 as illustrated in Table 6.

Table 5. Estimated design rainfall intensity levels according to duration and period of return

\begin{tabular}{|c|c|c|c|c|c|c|c|c|c|c|c|c|}
\hline N-year & \multicolumn{10}{|c|}{ Duration (h) } \\
\hline Event & 5 & 10 & 15 & 30 & 60 & 120 & 180 & 360 & 720 & 1440 \\
\hline & \multicolumn{10}{|c|}{ Maximum rainfall intensity (mm/h) } \\
\hline 2 & 276.1 & 219.8 & 185.9 & 133.5 & 87.4 & 47.3 & 32.6 & 17.4 & 9.2 & 4.9 \\
\hline 5 & 306.4 & 244.6 & 206.8 & 149.6 & 96.6 & 53.4 & 36.9 & 19.7 & 10.4 & 5.4 \\
\hline 10 & 338.2 & 267.8 & 227.8 & 163.6 & 106.2 & 58.8 & 39.6 & 21.7 & 11.6 & 5.9 \\
\hline 20 & 380.6 & 291.7 & 244.6 & 177.9 & 116.35 & 63.90 & 42.56 & 23.5 & 12.7 & 6.4 \\
\hline 50 & 430.7 & 320.5 & 271.8 & 195.7 & 128.75 & 70.00 & 47.40 & 25.60 & 14.0 & 6.9 \\
\hline 100 & 469.2 & 350.5 & 292.5 & 210.1 & 138.40 & 75.50 & 51.55 & 27.76 & 15.2 & 7.5 \\
\hline
\end{tabular}


Table 6. Simulation of future climate predictions in accordance with RCP4.5 and RCP8.5 scenarios for the years 2030, 2040, and 2050

\begin{tabular}{|c|c|c|c|c|c|c|c|c|}
\hline Year & RCPs & $\begin{array}{l}\text { Duration } \\
\text { (h) }\end{array}$ & $\begin{array}{c}\text { Peak discharge } \\
\left(\mathrm{m}^{3} / \mathrm{s}\right)\end{array}$ & $\begin{array}{c}\text { Rainfall } \\
\text { depth } \\
(\mathrm{mm}) \\
\end{array}$ & $\begin{array}{l}\text { First flood } \\
\text { time (t) }\end{array}$ & $\begin{array}{c}\text { First } \\
\text { flooded } \\
\text { node } \\
\end{array}$ & $\begin{array}{l}\text { Flash flood } \\
\text { time (t) }\end{array}$ & $\begin{array}{l}\text { flood depth above } \\
\text { crown }(\mathrm{m})\end{array}$ \\
\hline \multirow{6}{*}{2030} & \multirow{3}{*}{$\mathrm{RCP} 4.5$} & 1:00 & 14.82 & \multirow{3}{*}{120.1} & $0: 25$ & $2 \& 3$ & 1:00 & 2.387 \\
\hline & & 2:00 & 11.83 & & $0: 45$ & $2 \& 3$ & $1: 40$ & 1.699 \\
\hline & & 3:00 & 7.00 & & 0.50 & $2 \& 3$ & 1.50 & 0.497 \\
\hline & \multirow{3}{*}{ RCP 8.5} & 1:00 & 17.23 & \multirow{3}{*}{134.0} & $0: 10$ & $2,3 \& 4$ & $1: 00$ & 3.580 \\
\hline & & 2:00 & 13.58 & & $0: 45$ & $2 \& 3$ & $1: 45$ & 2.283 \\
\hline & & 3:00 & 8.13 & & $0: 50$ & $2 \& 3$ & 2.05 & 0.817 \\
\hline \multirow{6}{*}{2040} & \multirow{3}{*}{ RCP 4.5} & $1: 00$ & 15.75 & \multirow{3}{*}{125.5} & $0: 25$ & $2 \& 3$ & $1: 00$ & 2.618 \\
\hline & & 2:00 & 12.51 & & $0: 35$ & $2,3 \& 4$ & $1: 45$ & 1.921 \\
\hline & & 3:00 & 7.46 & & $0: 40$ & $2,3 \& 4$ & $1: 55$ & 0.613 \\
\hline & \multirow{3}{*}{ RCP 8.5} & 1:00 & 20.88 & \multirow{3}{*}{154.0} & $0: 20$ & $2,3 \& 4$ & $1: 00$ & 4.025 \\
\hline & & $2: 00$ & 16.52 & & $0: 35$ & $2,3 \& 4$ & $1: 45$ & 3.258 \\
\hline & & $3: 00$ & 9.84 & & $0: 40$ & $2,3 \& 4$ & 2.10 & 1.428 \\
\hline \multirow{6}{*}{2050} & \multirow{3}{*}{ RCP 4.5} & 1:00 & 20.22 & \multirow{3}{*}{150.5} & $0: 20$ & $2,3 \& 4$ & $1: 00$ & 3.829 \\
\hline & & $2: 00$ & 15.95 & & $0: 40$ & $2 \& 3$ & $1: 45$ & 3.068 \\
\hline & & 3:00 & 9.55 & & $0: 45$ & $2 \& 3$ & $2: 10$ & 1.315 \\
\hline & \multirow{3}{*}{ RCP 8.5} & 1:00 & 22.65 & \multirow{3}{*}{163.6} & $0: 10$ & $2,3 \& 4$ & $1: 00$ & 5.191 \\
\hline & & $2: 00$ & 17.90 & & $0: 40$ & $2,3 \& 4$ & $1: 50$ & 3.742 \\
\hline & & $3: 00$ & 10.73 & & $0: 45$ & $2 \& 3$ & $2: 10$ & 1.749 \\
\hline
\end{tabular}

Data collection allowed estimation of the rainfall for each target period under the assumptions of the RCP 4.5 and RCP 8.5 scenarios. Figure 5 shows the results for each target period in short durations. First, rainfall changes were indicated by implementing the 2-hour duration so as to generate the predicted rainfall for the study area, which were compared to the design requirements for storm depth (i.e. rainfall in the 2-hour duration over 10-year frequency) for the existing drainage network. Here, the rainfall intensity was $26.2 \%$ higher compared to the existing design standard. Meanwhile, modelling by using RCP4.5 and RCP8.5 scenarios in the year 2030 revealed an increase in rainfall depth at $28.8 \%$ and $43.7 \%$, which was greater than the existing design rainfall of $93.2 \mathrm{~mm}$. Similarly, the rainfall depth for 2040 and 2050 increased by $34.6 \%$ and $65 \%$, and $61.5 \%$ and $75.5 \%$, respectively, for both scenarios, which were higher than the existing design requirements as well. Moreover, the projected rainfall for all three potential periods was comparably larger than the actual rainfall value designed for the existing drainage network (Figure 7), whereas the predicted rainfall exceeded the precipitation limit for the current road drainage network. This reflects the remarkably inadequate ability of the current drainage network to handle potential rainfall.

In relation to the current drainage system flow volume, an increment of rainfall intensity would result in an increased drainage over-flow and flooding in some sites, thus yielding a high possibility for impacted existing road infrastructure. Accordingly, road flooding could cause serious infrastructure problems and considerable economic losses, thus generating serious damage to public properties and other infrastructures.

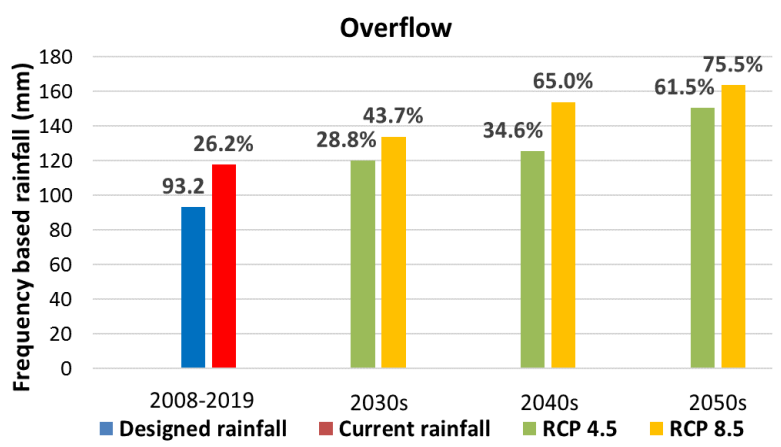

Figure 7. Comparison of rainfall design, current rainfall, and predicted rainfall based on the maximum value of rainfall intensity

Then, runoff simulation was conducted for the targeted area by using a two-hour frequency-based estimated precipitation to the review surface runoff variance in view of the worst-case scenario due to an observed increase in the current rainfall intensity, whereby the RCP4.5 and RCP8.5 scenarios were simulated. In particular, the simulation outcomes for the year 2030 showed that five junctions were flooded, whereby the estimated flood depth was $2.28 \mathrm{~m}$.

Meanwhile, the results for the year 2040 revealed that seven junctions were flooded in which the estimated flood 
depth was exceptionally high at $3.25 \mathrm{~m}$. Finally, the outcomes for the year 2050 indicated that 10 junctions were flooded and the estimated flood depth was $3.74 \mathrm{~m}$. As a result of the simulations, a short rainfall period with high rainfall intensity resulted in a high discharge in urban road drainage (Table 3-5), which was thus recognised as the primary cause of flooding.

\subsection{Implication for Road Structure Design}

A comparison of the flood depth in road structures as illustrated in Figure 1 for the storm revealed that the flood depth exceeded the road structure dimension for the existing road drainage system. Furthermore, the simulated scenarios of RCP4.5 and RCP8.5 both showed a rise in flood depth at Junctions 2, 3, and 4. Meanwhile, in all storms, the storm depth in both scenarios also impacted the dimensions of Junctions 2, 3, and 4 road structures (Table 7). Regardless, data obtained from the nearest rainfall station in the study area revealed that the floods exceeded on the design capacity of the current drainage network and matched a prior intense rainfall event at the return period of five years. Moreover, the climate change scenarios for the depth of water at Junctions 2, 3, and 4 during the major future storm events in the years of 2030 , 2040, and 2050 further demonstrated the presence of a problem in the drainage network dimensions for the current area under future possible climate change. In contrast, other junctions showed that none of the climate scenarios resulted in significant water level changes; at the very least, no overcapacity in design was seen.
To accommodate the expected potential climatic changes, it would be highly necessary to assess the manner in which the drainage system could be improved for the most severely affected junctions simulated by SWMM 5.1. In comparison, the simulated depth of water at 12 junctions indicated that its dimensions were adequate; however, an exception could be depicted when looking at Junctions 2, 3, and 4 in the 2-hr duration under current and future climate change potentials. Accordingly, the climate scenario contributed to the significant changes in water level for all storms. Besides, it should be noted that the model limitations indicate that the findings in (Table 6) provide a valid approximation despite them being considered as somewhat conservative.

Moreover, the model did not consider instances such as waste accommodation and related drain system blockage (i.e. due to drifting plants and waste) as a result of lacking maintenance. The road drainage system was constructed in 1996; as shown in (Table 7), the current drainage system is incapable of accommodating the current amount of rainfall during its design lifetime, which is up to 50 to 60 years depending on the design standards. Therefore, this indicates the need for its replacement and redesign. Finally, generalised doubts could be raised about the potential climate changes in specific regional and national climate conditions. The findings offered clearly revealed different potential scenarios that were quite different from the reality.

Table 7. The highest simulated water level in the region of Seri Kembangan road catchment during historical storm events of 2-hour duration and in different scenarios used for SWMM 5.1 simulation; water depth in bold exceeding the depth of the structures

\begin{tabular}{|c|c|c|c|c|c|c|c|c|c|c|}
\hline \multirow{3}{*}{$\begin{array}{l}\text { Event used } \\
\text { in the } \\
\text { simulation }\end{array}$} & \multirow{3}{*}{$\begin{array}{l}\text { Duration } \\
\text { (h) }\end{array}$} & \multirow{3}{*}{$\begin{array}{l}\text { Structure } \\
\text { (junction) }\end{array}$} & \multirow{3}{*}{$\begin{array}{c}\text { Designed } \\
\text { drainage } \\
\text { depth } \\
\text { (m) }\end{array}$} & \multicolumn{7}{|c|}{ Highest simulated water depth above crown (m) } \\
\hline & & & & \multirow{2}{*}{ Base } & \multicolumn{2}{|c|}{2030} & \multicolumn{2}{|c|}{2040} & \multicolumn{2}{|c|}{2050} \\
\hline & & & & & $\mathrm{RCP} 4.5$ & $\mathrm{RCP} 8.5$ & $\mathrm{RCP} 4.5$ & $\mathrm{RCP} 8.5$ & $\mathrm{RCP} 4.5$ & RCP8.5 \\
\hline \multirow{3}{*}{$\begin{array}{c}21^{\text {st }} \text { April } \\
2014 \\
(10 \text {-year } \\
\text { storm })\end{array}$} & \multirow{3}{*}{2} & $\mathrm{~J}-2$ & 1.20 & 0.778 & 1.596 & 2.178 & 1.817 & 3.154 & 2.965 & 3.638 \\
\hline & & $\mathrm{J}-3$ & 0.45 & 0.883 & 1.699 & 2.283 & 1.921 & 3.258 & 3.068 & 3.742 \\
\hline & & $\mathrm{J}-4$ & 0.45 & 0.738 & 1.451 & 1.942 & 1.636 & 2.749 & 2.598 & 3.140 \\
\hline
\end{tabular}




\subsection{Impact of Changes in Return Periods on Peak Flow and Drainage Network Capacity for Different Return Periods}

According to the study area, the rainfall intensity values ranged from 93.3 to $151 \mathrm{~mm}$ for the 2-hr rainfall duration and a return period of 2 to 100 -year, respectively. Here, different values were chosen in line with the local practices and their significance for design purposes according to various infrastructures. Therefore, the return period may vary from 2 to 50 or even 100 years depending on the nature of the structure and its cost: the cost may be obviously higher if the return period chosen for its design is higher. (Figure 8) shows that the rainfall intensity increases by $28.1 \%$ in the instance wherein the return period selected is 100 years instead of 10 years. Similarly, the values of rainfall intensity obtained were $117.7 \mathrm{~mm} / \mathrm{h}$ for a return period of 10 -year, whereas it would be $151 \mathrm{~mm} / \mathrm{h}$ for a return period of 100 -year for the 2-hr duration.

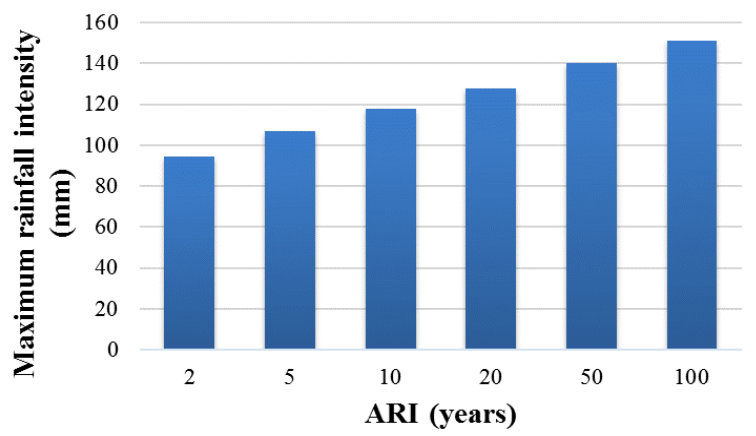

Figure 8. Probability maximum rainfall intensity for various return periods for the study area

Malaysia commonly practises the designing of road stormwater drainage system based on the local standards for a 10 -year return period storm. In contrast, the findings recommended the adoption periods of 100 years for a higher safety factor in the affected areas. Henceforth, the effect of design return time changes on the trunk drainage channel peak flow and dimension is illustrated in (Figures $9 \& 10)$. It was observed that a reduction in the design return period from 100 to 10 years would reduce the drainage capacity by $28.1 \%$.

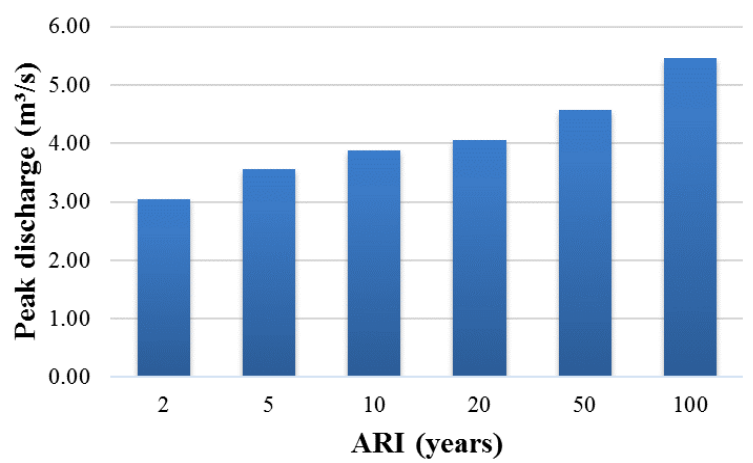

Figure 9. Peak runoff variation with return period of main storm drainage

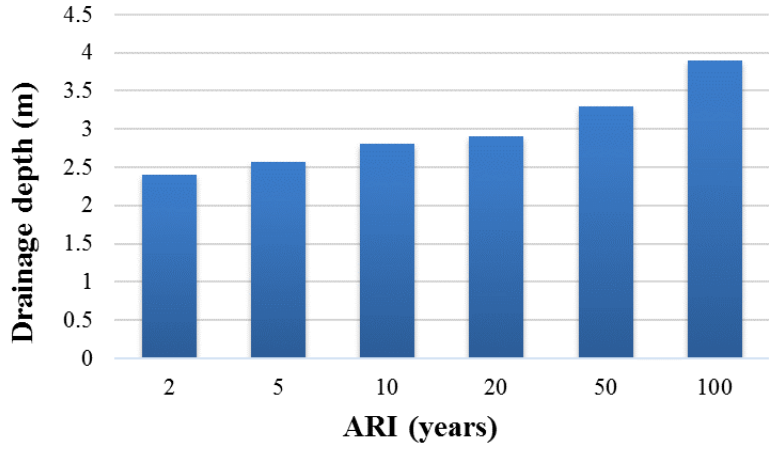

Figure 10. Return period variability in main storm channel design depth

Moreover, the current study showed significant changes in the precipitation patterns for the study zone during the period spanning from the year 2008 to 2017. As future predictions yielded a high increase in precipitation, sustainable development of the current drainage network should be re-evaluated. In particular, the current drainage system capacity was at about $28.1 \%$ smaller than the design capacity in order to handle any runoff due to rainfall over the 100 -year return period.

\section{Conclusions}

The study outcomes revealed that a majority of the existing drainage capacity for the study area borderline was insufficient to carry out the excessive runoff created by using the updated IDF curve. Nonetheless, the existing status of a stormwater system for the study zone in the context of its ability, sort, drainage age, and long-term pattern have indicated the deterioration of current infrastructure due to unintended neglect and changes in land use. Besides, the drainage network for the study area was designed in 1996; therefore, the impermeable surfaces were smaller back then than those of today as urban growth was consistently and rapidly growing annually, thus significantly affecting the urban runoff. Furthermore, a majority of the hazards encountered regarding the sustainability of Malaysian road drainage is linked to rainfall and runoff in various ways. Besides, potential climate change would contribute to more regular and extreme precipitation events, which result in higher peak discharges and cause more road infrastructure damage.

For future scenarios, the hydrological model used in this study was geared for simulating and quantifying such changes, whereby the application of SWMM 5.1 showed changes of peak-discharge and water depth across three different climate scenarios in the years of 2030, 2040, and 2050 over the 2-hour duration. The highest simulated peak discharge was in Junction 3 based on RCP4.5 and RCP 8.5 scenarios for the three different climate scenarios; in 2030,2040 , and 2050, the peak discharge was $11.83 \mathrm{~m}^{3} / \mathrm{s}$ and $13.58 \mathrm{~m}^{3} / \mathrm{s}, 12.51 \mathrm{~m}^{3} / \mathrm{s}$ and $16.52 \mathrm{~m}^{3} / \mathrm{s}$, and $15.95 \mathrm{~m}^{3} / \mathrm{s}$ and $17.90 \mathrm{~m}^{3} / \mathrm{s}$, respectively. Besides, the highest 
simulated water depth was in Junction 3 as well; it yielded values in the year of 2030, 2040, and 2050 for both scenarios as follows, respectively: $1.699 \mathrm{~m}$ and $2.283 \mathrm{~m}$, $1.921 \mathrm{~m}$ and $3.258 \mathrm{~m}, 3.068 \mathrm{~m}$ and $3.742 \mathrm{~m}$. In addition, the extent to which the changes were varied was in line with the storm scale, whereas the rise in peak-flow and water-level was linked more pertinently to the size of the storm and the change in land use.

Additionally, the analysis presented in this study employed the current and latest future climate scenarios of RCP4.5 and RCP8.5 to assess the urban road drainage systems. Therefore, the inadequate ability of the road drainage system to handle greater volumes of rainstorms as seen in this study and predicted using the climate change scenarios underlines the need for its improvement and enhancement. This may thus be done by increasing the return period from 10-year to 100-year ARI to reduce the flood depth on urban roads. Besides, the current drainage system capacity is approximately $28.1 \%$ less than the design capacity for handling the runoff as a result of the 100-year return period rainfall. Therefore, making decisions on the adaptation or construction of road drainage systems should be preceded by the authorities obtaining more information about the potential changes in climate change-related discharge behaviours. Thus, the typical process presented in this study may position its capability as a scientific approach to evaluate the adequacy of existing road drainage systems.

\section{Acknowledgements}

The authors would like to express their gratitude to the Department of Irrigation and Drainage (DID) and National Hydraulic Research Institute of Malaysia (NAHRIM), for providing meteorological data reports for Seri Kembangan region and the authors also express their gratitude for the financial support by Universiti Kebangsaan Malaysia (UKM).

\section{REFERENCES}

[1] MMD: Climate change scenarios for Malaysia Scientific Report 2001-2099. Numerical Weather Prediction Development Section Technical Development Division, Malaysian Meteorological Department Ministry of Science, Technology and Innovation Kuala Lumpur, 2009

[2] Niemczynowicz J: Impact of the greenhouse effect on sewerage systems - Lund case study. Hydrol Sci Journal/Journal Des Sci Hydrol 34(6):651-66, 1989

[3] Watt WE:, Waters D:, McLean R: Report 2003-1: Climate Change and Urban Stormwater Infrastructure in Canada: Context and Case Studies, 2003, pp. 1-30

[4] Papa F:, Guo Y:, Thoman GW: Urban drainage infrastructure planning and management with a changing climate. 57th Canadian Water Resources Association Annual Congress - Water and Climate Change: Knowledge for Better Adaptation, Montréal, QC, (1-6), 2004

[5] Ashley RM:, Balmfort DJ:, Saul AJ:, Blanskby JD: Flooding in the future - Predicting climate change, risks and responses in urban areas. Water Sci Technol 52(5):265-73, 2005. Doi: DOI: 10.2166/wst.2005.0142

[6] Ibrahim B:, Karambiri H:, Polcher J: Hydrological Impacts of the Changes in Simulated Rainfall Fields on Nakanbe Basin in Burkina Faso. Climate 3:442-58, 2015. Doi: 10.3390/cli3030442

[7] Denault C:, Millar RG:, Lence BJ: Assessment of possible impacts of climate change in an urban catchment. $J \mathrm{Am}$ Water Resour Assoc 42(3):685-97, 2006. Doi: 10.1111/j.1752-1688.2006.tb04485.x

[8] Zhou Q:, Panduro TE:, Thorsen BJ:, Arnbjerg-Nielsen K: Adaption to extreme rainfall with open urban drainage system: An integrated hydrological cost-benefit analysis. Environ Manage 51(3):586-601, 2013. Doi: $10.1007 / \mathrm{s} 00267-012-0010-8$

[9] Shaaban AJ:, Amin MZM:, Chen ZQ:, Asce M:, Ohara N:, Asce AM: Regional Modeling of Climate Change Impact on Peninsular Malaysia Water Resources (December):1040-9, 2011. Doi: 10.1061/(ASCE)HE.1943-5584

[10] MENG SEI KWAN FTT\& LJ: Projected Changes of Future Climate Extremes in Malaysia. Sains Malaysiana 42(8):1051-9, 2013

[11] Adger W.: "Assessment of adaptation practices, options, constraints and capacity Coordinating." Contribution of Working Group II to the Fourth Assessment Rep. of Intergovernmental Panel on Climate Change, Cambridge University Press, Cambridge, U.K., 717-743. Cimate Chang 200(July):717-43, 2007

[12] Fowler AM:, Hennessy KJ: Potential impacts of global warming on the frequency and magnitude of heavy precipitation. Nat Hazards 11(3):283-303, 1995. Doi: 10.1007/BF00613411

[13] Molavi et al.: Implementing Future Climate Change Scenarios Using a Stormwater Drainage Model for an Urban Catchment in Melbourne. 20Th Int Congr Model Simul (December):2820-6, 2013

[14] Willems P: Compound intensity/duration/frequency-relatio nships of extreme precipitation for two seasons and two storm types. J Hydrol 233(1-4):189-205, 2000. Doi: 10.1016/S0022-1694(00)00233-X

[15] Syafrina AH:, Zalina MD:, Norzaida A: Climate Projections of Future Extreme Events in Malaysia. Am J Appl Sci 14(3):392-405, 2017. Doi: 10.3844/ajassp.2017.392.405

[16] Egeru A:, Barasa B:, Nampijja J:, Siya A:, Makooma MT:, Majaliwa MGJ: Past, present and future climate trends under varied representative concentration pathways for a sub-humid region in Uganda. Climate 7(3), 2019. Doi: 10.3390/cli7030035

[17] Denault C: Assessment of the likely impact of climate change on infrastructure and natural ecosystems of a small watershed in British Columbia: Implications for hydraulic 
infrastructure design and stormwater management. University of British Columbia, 2001

[18] Res C:, Scheraga JD:, Grambsch AE: Risks , opportunities , and adaptation to climate change 10:85-95, 1998

[19] Hamidon N:, Harun S:, Sunar NM:, Hamid NHA:, Muhamad MS:, Harun H:, Ali R:, Awang M:, Rahman MAA:, Ahmad F:, Musa K:, Yusof FM:, Mustafa MSS: Prediction of future climate change for rainfall in the upper kurau river basin, perak using statistical downscaling model (SDSM). Civ Eng Archit 7(6):33-42, 2019. Doi: 10.13189/cea.2019.071404

[20] Butler, D., and Davies J: URBAN DRAINAGE. Third Edit. New York: Spon Press, Taylor \& Franceis, New York.1-652, 2010.

[21] Endreny TA:, Imbeah N: Generating robust rainfall intensity-duration-frequency estimates with short-record satellite data. J Hydrol 371(1-4):182-91, 2009. Doi: 10.1016/J.JHYDROL.2009.03.027

[22] Green Paper EU 2007: Adapting to Climate Change in Europe - Options for EU Action 33(September):1-6, 2007

[23] Gordon HB:, Whetton PH:, Pittock AB:, Fowler AM:, Haylock MR: Simulated changes in daily rainfall intensity due to the enhanced greenhouse effect: implications for extreme rainfall events. Clim Dyn 8(2):83-102, 1992. Doi: 10.1007/BF00209165

[24] Grum M:, Jørgensen AT:, Johansen RM:, Linde JJ: The effect of climate change on urban drainage: An evaluation based on regional climate model simulations. Water $S c i$ Technol 54(6-7):9-15, 2006. Doi: 10.2166/wst.2006.592

[25] Koutsoyiannis D:, Kozonis D:, Manetas A: A mathematical framework for studying rainfall intensity-duration-frequenc y relationships 206(1-2):118-35, 1998

[26] Olofsson M: Climate Change and Urban Drainage: Future Precipitation and Hydraulic Impact. Lulea University of Technology, SE-971 87 Lulea Sweden. 1-77,. 2007

[27] Neumann JE:, Price J:, Chinowsky P:, Wright L:, Ludwig L:, Streeter R:, Jones R:, Smith JB:, Perkins W:, Jantarasami L:, Martinich J: Climate change risks to US infrastructure: impacts on roads, bridges, coastal development, and urban drainage. Clim Change 131(1):97-109, 2015. Doi: 10.1007/s10584-013-1037-4

[28] Willems P:, Arnbjerg-Nielsen K:, Olsson J:, Nguyen VTV: Climate change impact assessment on urban rainfall extremes and urban drainage: Methods and shortcomings. Atmos Res 103:106-18, 2012. Doi:

10.1016/j.atmosres.2011.04.003

[29] Al-Ghadi MS:, Mohtar WHMW:, Razali SFM:, El-Shafie A: The Practical Influence of Climate Change on the Performance of Road Stormwater Drainage Infrastructure. $J$ Eng 2020, 2020. Doi: https://doi.org/10.1155/2020/8582659

[30] Arnbjerg-Nielsen K:, Willems P:, Olsson J:, Beecham S: Pathirana A:, Bülow Gregersen I:, Madsen H:, Nguyen VTV: Impacts of climate change on rainfall extremes and urban drainage systems: A review. Water Sci Technol 68(1):16-28, 2013. Doi: $10.2166 /$ wst.2013.251

[31] Zhou Q: A review of sustainable urban drainage systems considering the climate change and urbanization impacts. Water (Switzerland) 6(4):976-92, 2014. Doi:

\section{$10.3390 / \mathrm{w} 6040976$}

[32] Berggren K:, Olofsson M:, Viklander M:, Svensson G:, Gustafsson AM: Hydraulic Impacts on Urban Drainage Systems due to Changes in Rainfall Caused by Climatic Change. J Hydrol Eng 17(1):92-8, 2011. Doi: 10.1061/(ASCE)HE.1943-5584.0000406

[33] Sampson CC:, Bates PD:, Neal JC:, Horritt MS: An automated routing methodology to enable direct rainfall in high resolution shallow water models. Hydrol Process 27(3):467-76, 2013

[34] Kalantari Z:, Briel A:, Lyon SW:, Olofsson B:, Folkeson L: On the utilization of hydrological modelling for road drainage design under climate and land use change. Sci Total Environ 475:97-103, 2014. Doi: 10.1016/j.scitotenv.2013.1 2.114

[35] Kalantari Z:, Folkeson L: Road Drainage in Sweden: Current Practice and Suggestions for Adaptation to Climate Change. J Infrastruct Syst 19(June):120815054110004, 2012. Doi: 10.1061/(ASCE)IS.1943-555X.0000119

[36] Eisenack K:, Stecker R:, Reckien D:, Hoffmann E: Adaptation to climate change in the transport sector: A review of actions and actors. Mitig Adapt Strateg Glob Chang 17(5):451-69, 2012. Doi: 10.1007/s11027-011-9336 $-4$

[37] Adger WN:, Dessai S:, Goulden M:, Hulme M:, Lorenzoni I:, Nelson DR:, Naess LO:, Wolf J:, Wreford A: Are there social limits to adaptation to climate change? Clim Change 93(3-4):335-54, 2009. Doi: 10.1007/s10584-008-9520-z

[38] Brizikova L:, Neale T:, Burton I: Canadian Communities' Guidebook for Adaptation to Climate Change: Including an Approach to Generate Mitigation Co-benefits in the Context of Sustainable Development, 1st ed. ; Environment Canada and British Columbia University, Vancouver, 2008

[39] Klas Hansson V:, Fredrik Hellman V:, Marianne Grauert D:, Michael Larsen D: THE BLUE SPOT CONCEPT, Road Directorate, Danish Road Institute, 1-34, 2010

[40] Pedrozo-Acuña A:, Moreno G:, Mejía-Estrada P:, Paredes-Victoria P:, Breña-Naranjo JA:, Meza C: Integrated approach to determine highway flooding and critical points of drainage. Transp Res Part D Transp Environ 50:182-91, 2017. Doi: 10.1016/j.trd.2016.11.004

[41] Kessides C: The contributions of infrastructure to economic development: a review of experience and policy implications. World Bank Discuss Pap 213(c):1-52, 1993

[42] Bollinger LA:, Bogmans CWJ:, Chappin EJL:, Dijkema GPJ:, Huibregtse JN:, Maas N:, Schenk T:, Snelder M:, van Thienen P:, de Wit S:, Wols B:, Tavasszy LA: Climate adaptation of interconnected infrastructures: A framework for supporting governance. Reg Environ Chang 14(3):91931, 2014. Doi: 10.1007/s10113-013-0428-4

[43] Koetse MJ:, Rietveld P: The impact of climate change and weather on transport: An overview of empirical findings. Transp Res Part D Transp Environ 14(3):205-21, 2009. Doi: 10.1016/J.TRD.2008.12.004

[44] Melvin AM:, Larsen P:, Boehlert B:, Neumann JE:, Chinowsky P:, Espinet X:, Martinich J:, Baumann MS:, Rennels L:, Bothner A:, Nicolsky DJ:, Marchenko SS: 
Climate change damages to Alaska public infrastructure and the economics of proactive adaptation. Proc Natl Acad Sci U $S$ A 114(2):E122-31, 2017. Doi: 10.1073/pnas.1611056113

[45] Yunianta A:, Setiadji BH:, Suripin: Sustainable road Experimental model drainage system: 11005, 2018. Doi: 10.1051/matecconf/201818111005

[46] Yunianta A:, Suripin S:, Setiadji BH: Application of sustainable road drainage system: simulation by using SWMM program. Civ Eng Archit 8(2), 2020. Doi: DOI: 10.3189/cea.20.08203

[47] Fischer G:, Tubiello FN:, Van Velthuizen H:, Wiberg DA: Climate change impacts on irrigation water requirements: Effects of mitigation, 1990-2080. Technol Forecast Soc Change 74(7):1083-107, 2007. Doi: DOI: 10.1016/j.techfore.2006.05.021

[48] Van Vuuren DP:, Edmonds J:, Kainuma M:, Riahi K:, Thomson A:, Hibbard K:, Hurtt GC:, Kram T:, Krey V:, Lamarque J-F: The representative concentration pathways: an overview. Clim Change 109(1-2):5, 2011. Doi: DOI: 10.1007/s10584-011-0148-Z

[49] Moss R:, Babiker W:, Brinkman S:, Calvo E:, Carter T:, Edmonds J:, Elgizouli I:, Emori S:, Erda L:, Hibbard K: Towards new scenarios for the analysis of emissions: Climate change, impacts and response strategies. vol. 25. Intergovernmental Panel on Climate Change, Geneva, 132 pp, 2008.

[50] Dlamini NS:, Kamal MR:, Soom MABM:, Mohd MSF bin:, Abdullah AF Bin:, Hin LS: Modeling potential impacts of climate change on streamflow using projections of the 5th assessment report for the bernam river basin, Malaysia. Water (Switzerland) 9(3):1-23, 2017. Doi: 10.3390/w9030226

[51] Meinshausen M:, Smith SJ:, Calvin K:, Daniel JS:, Kainuma MLT:, Lamarque J:, Matsumoto K:, Montzka SA:, Raper SCB:, Riahi K:, Thomson A:, Velders GJM:, van Vuuren DPP: The RCP greenhouse gas concentrations and their extensions from 1765 to 2300. Clim Change 109(1):213-41, 2011. Doi: 10.1007/s10584-011-0156-Z
[52] Wayne G: The Beginner's Guide to Representative Concentration Pathways.Representative Concentration Pathways ( RCPs)

[53] Majlis Perbandaran Subang Jaya (MPSJ).: Flood mitigation work kicks off in Seri Kembangan. https://www.edgeprop.my//content/1508359/flood-mitigatio n-work-kicks-seri-kembangan (Nov. 25, 2019).

[54] NST TV: Sungai Besi highway cut off due to floods [VIDEO]. https://www.nst.com.my/news/sungai besi highway cut due floods video (accessed Jan. 9, 2018).

[55] MSMA 2th edition.: Urban stormwater management manual, the Standard Design of Drainage System in Malaysia. Government of Malaysia, Department of Irrigation and Drainage (DID) Malaya, Kuala Lumpur, Malaysia, 2012.

[56] Guo Y: Updating Rainfall IDF Relationships to Maintain Urban Drainage Design Standards. J Hydrol Eng 11(5):5069, 2006. Doi: 10.1061/(ASCE)1084-0699(2006)11:5(506)

[57] Okonkwo GI:, Mbajiorgu CC: Rainfall intensity-duration-fr equency analysis for Southeastern Nigeria. Agric Eng Int CIGR J 12(1), 2010

[58] G. Mamo: Evaluation of the Potential Impact of Rainfall Intensity Variation due to Climate Change on Existing Drainage Infrastructure. $J$ Irrig Drain Eng 141(10):05015002, 2015. Doi: 10.1061/(asce)ir.1943-4774. 0000887

[59] Yousef LA:, Ouarda TBMJ: Adaptation of Water Resources Management to Changing Climate: The Role of Intensity-Duration-Frequency Curves. Int J Environ Sci Dev 6(6):478-83, 2015. Doi: 10.7763/ijesd.2015.v6.641

[60] Rossman L:, Huber W: Storm Water Management Model Reference Manual Volume I, II and III. Washington, DC. EPA/600/R-15, 2015.

[61] AASHTO: Drainage Manual. American Association of State Highway and Transportation Officials, Washington D.C, ISBN 978-1-56051-564-7, 1. vol. 1, 2014. 